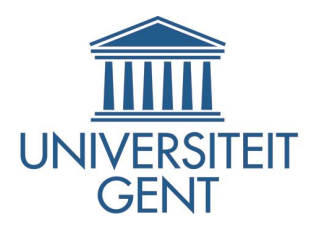

biblio.ugent.be

The UGent Institutional Repository is the electronic archiving and dissemination platform for all UGent research publications. Ghent University has implemented a mandate stipulating that all academic publications of UGent researchers should be deposited and archived in this repository. Except for items where current copyright restrictions apply, these papers are available in Open Access.

This item is the archived peer-reviewed author-version of:

African Verbal Arts and the Study of African Visual Aesthetics

Wilfried van Damme

In: Research in African Literatures 31 (4), pp. 8-20, 2000

To refer to or to cite this work, please use the citation to the published version:

Wilfried van Damme (2000. African Verbal Arts and the Study of African Visual Aesthetics. Research in African Literatures (31/4): 8-20. DOI 10.1353/ral.2000.00117 


\title{
African Verbal Arts and the Study of African Visual Aesthetics
}

\author{
Wilfried van Damme
}

In this paper I would like to briefly explore the possibilities that research into African verbal arts presents for an understanding of 'aesthetics' in African cultures. When used in African studies, by both non-indigenous and indigenous scholars, the Western derived label aesthetics generally serves to refer to a given culture's views on 'beauty' or related qualities. Scholarly attention has until now been largely focused on beauty as an attribute of human beings and of anthropomorphic renditions in statuary art and masked performances, in addition to several other visual phenomena. Although analyses of African verbal arts, both oral and written, may also instruct us on notions of quality in non-visual domains, in the present paper emphasis will be on what the opinions that are expressed in various literary types may teach us about the aesthetics informing the creation and evaluation of the visual arts in African cultures. While in keeping with the focus of this special issue of Research in African Literatures, this emphasis also reflects a disciplinary bias of the present author who has a background in African visual art studies.

Although in African studies aesthetics usually refers to the idea of beauty, a limited number of scholars in this field--additionally--employ the term in the sense in which it has been used by most twentieth-century Western philosophers, namely as pertaining to 'the philosophy of art'. In the West, this conception of the label aesthetics has come to refer to--the study of--the philosophical views that throughout the documented history of Western thinking have been 
expressed vis-a-vis the phenomena of 'art and beauty'. Indeed, at least from the time of the ancient Greeks onwards, philosophers and others in

the West have been concerned with reflections on such topics as the origin and nature of the arts, their classification and various functions, the creativity and inspiration involved in their production, the experience and evaluation of their qualities, and the nature of these qualities themselves. In recent decades both Western and non-Western scholars have started to address the views which have been expressed on these and related topics in non-Western cultures. Attention has until now been leveled particularly at the literate traditions of Oriental cultures, whereas research into the art philosophical views of so-called non-literate or traditionally oral cultures has only just begun. Although the latter views do not constitute the main focus of this paper, I would like to seize the opportunity to encourage literary and other scholars to investigate art philosophical topics through the study of African oral traditions, in order also to thus contribute to the emerging field of study of 'intercultural philosophy of art' or 'world aesthetics'. ${ }^{1}$

If in this paper I draw attention to African literary types as potentially rich sources of information on aesthetics, I am simply echoing the calls that several African scholars have made during the past few decades. In one of the first essays on African aesthetics written by an African scholar, Harris Memel-FotL already briefly suggested that we turn to the verbal arts in our attempts to learn about African views on beauty: "Ecoutons les contes et les IJgendes... dJpositaires de l'esthJtique" ("Let us listen to the tales and legends... depositories of the aesthetic") (50). Memel-FotL argues that a consideration of the various literary types will inform us on the range of natural and human-made objects considered beautiful in African cultures. Furthermore, in a somewhat different context he suggests that the study of verbal art forms in 
Africa may also teach us about more philosophical views on matters aesthetic. Memel-FotL more specifically refers to two "contes philosophiques" ("philosophical tales") of the Bete of $\mathrm{C}^{\wedge}$ te d'Ivoire which are concerned with the relative nature of aesthetic judgments. In one of these, a male chimpanzee and antilope are held captive near a village. The antilope is longing for his lovers who, down in the forest, are grieving for his absence. The chimpanzee thereupon expresses a similar yearning. The antilope is quite surprised to hear that the chimpanzee has lovers at home who regret his absence. For is not the ugliness of the monkey proverbial? To which the monkey replies, "Retiens simplement qu'il n'y a de laideur absolue de chimpanzJ qu'au village et dans l'esprit des antilopes et autres animaux" ("Just remember that the absolute ugliness of the chimpanzee does not exist but in the village and in the minds of antilopes and other animals") (51).

Unfortunately, we are not informed about the contexts in which such philosophical tales are told among the Bete, nor are we provided with other relevant information concerning, for example, the persons involved in creating, transmitting, and amending these tales. Ideally, we should also be presented with the original Bete versions, together with an extensive examination of the key concepts involved, such as in this case the notion of 'ugliness'.

Several African scholars have since made similar pleas for directing attention to the verbal arts in the context of studying African aesthetics, most notably Yoruba scholars like Rowland Abio*dun, to whom we shall return. Likewise, in a recent publication Mohamed Abusabib observes that it is well known to specialized scholars that "in non-literate societies oral traditional forms are the reservoir of theoretical and practical knowledge. Proverbs, sayings, dictums, verse and many other poetic formulations are loaded with meaning reflecting the 
society's outlook and experience in all aspects of life" (76). This then also applies to the "African aesthetic outlook" which is directly and indirectly expressed in various forms of oral tradition that "usually contain deep artistic and aesthetic insights which reflect the prevalent principles and canons of criticism, evaluation, creativity, etc." (30). Abusabib relates that in his field work based MA thesis dealing with the aesthetics of adornment among the Shaigiya of northern Sudan, "One chapter is devoted to proverbs, sayings, and fragments of poems which give more clues to the traditional aesthetic outlook..." $\left(30\right.$, n.31). ${ }^{2}$ As an example, he refers to the Shaigiya proverb $A l$ ilgi mabtazeed khilgi, which he does not translate, but of which he says: "This proverb has two connotations: one is direct, and simply refers to ornament as something that cannot give beauty to the human form if the human form is in itself not beautiful; the other is indirect, and asserts that ornament could not be of help to the ugly" (76).

Abusabib also shows an awareness of the difficulties involved in approaching oral traditions as a source of data on aesthetics, emphasizing that "only those who have had first-hand experience of these cultures can pick up the clues offered by these statements and delve further into their meaning" (30). It is indeed true that forms of oral tradition, which may be quite cryptic to a cultural outsider, frequently need to be contextualized on several levels before their actual significance for understanding aesthetic views is revealed to the analyst. Several dimensions of the problems involved in the contextualization and interpretation of oral traditions relating to aesthetics will be touched upon below. Here we may consider the following associated topic.

In expressing his methodological concerns, Abusabib does not, however, question a basic assumption that would seem to underlie virtually all calls for considering the verbal arts as valuable sources of information on aesthetics. According to this assumption, the relevant forms of 
oral tradition embody the communis opinio in matters aesthetic. Abusabib in fact explicitly endorses this assumption when he observes that, in comparison to the data which individuals in a given culture provide on aeasthetics, "traditional oral forms--that is, proverbs and sayings, etc.-are more rewarding and far more reliable, since they are usually the products of deep and refined thinking which certainly reflects the communal experience of the people" (30). A similar line of reasoning has been employed by Cornelius Adepegba in drawing attention to the verbal arts as tools for understanding African visual arts and aesthetics. He notes that it is his experience among the Yoruba of Nigeria that people acting as informants "sometimes give information which would make themselves or their activities appear important or mysterious" (21). Informants' statements should therefore be balanced by taking into account information that is "extracted from the language", and which is "more likely to be free of personal bias. Languages are the unbroken transmitter of a people's past" (21). Adepegba therefore advises students of African visual arts and aesthetics to seriously consider linguistic data, including transmitted verbal art forms, which "would perhaps reduce some of the unnecessary mysticism with which African art may have been inadvertently surrounded" (21).

The crucial question regarding the extent to which forms of oral tradition reflect shared views is no doubt related to the type of oral tradition or verbal art we are concerned with, which may range from commonly employed proverbs to esoteric literary types the knowledge of which is limited to a select group of people in a given culture, who may additionally differ as to the interpretation of the content of these verbal art forms.

Of all the forms of oral tradition in Africa, it is particularly proverbs and sayings that are commonly held to express consensual views. For example, Kwesi Yankah, while noting that 
African concepts corresponding to the Western notion of proverb are usually more encompassing, including, say, the idea of parable, anecdote, or tale (237), conceives of a proverb as a "cultural truism" (326). However accepted the view that proverbs express collective opinions, as Mineke Schipper has pointed out, we should always try to critically assess the degree of catholicity of a proverb, as well as to consider who utters them in which context, thereby taking into account which perspectives and interests are at issue (14). Given the problems of interpretation that proverbs and other literary types pose to an outsider, an additional epistemological and methodological concern should be that scholars pay close attention to the perspectives and interests of those cultural spokespersons who provide researchers with an exegesis. As with other forms of oral tradition, the reference to proverbs in the context of--consensual--notions of beauty and related qualities should therefore ideally be combined with the results of other types of investigation into aesthetics (see also below).

Proverbs in African cultures may indeed in various ways provide interesting entries into views on beauty. This is clearly demonstrated in a study of Bwenge Kule Mate, whose analysis of the aesthetics of the Nande (Kivu region, Congo) is primarily based on a detailed consideration of several Nande proverbs and sayings pertaining to beauty. The examples provided and discussed by Mate, which are said to be predominantly used in the education of youngsters, concern, among other things, the transitory character of physical beauty, as in the saying, vuvuya vunahera, "la beautJ est JphJmPre" ["beauty is ephemeral"](246). This theme is in itself related to the relationship between outer and inner beauty of human beings, which is referred to, for example, in the saying, ovuvuya si mutima, "la beautJ n'est pas le coeur" ["beauty is not the heart"](246).

Mate prefaces his observations on proverbs by an analysis of the semantic fields and 
contexts of application of Nande nouns that are interpreted to refer to the idea of beauty as an attribute of human beings--as regards both their physical appearance and their character and conduct--and objects. This type of information is in fact indispensable for an appropriate contextual interpretation of proverbs referring to beauty. Still, this information is usually missing, not only in the more obvious cases where all that is available are translations into English, French, or any other language, but also when the proverb is cited in its original language. An in-depth study of the aesthetic vocabulary, including its expression in the verbal arts, should indeed occupy a central place in any examination of aesthetics in a given culture (Van Damme Beauty 193-98). ${ }^{3}$

The relationship between inner and outer beauty that is the subject matter of some of the Nande proverbs considered by Mate is also addressed in several of the African proverbs relating to female beauty that Schipper has collected. Thus it is said among the Kundu of Cameroon that "Beauty is an empty calebash", while according to a Swahili proverb, "The beauty of a woman does not reside in her face" (88). Similarly, among the Igbo of Nigeria the relationship between the physical qualities and character of a woman is the subject of several set phrases. As Chike Aniakor points out, an Igbo girl or woman who is considered to be physically attractive, but is deemed to have a bad character, may be referred to as agu mara mma mana obi ya abula agbara, "the beautiful leopard with the heart of an alusi (deity)", o mara mma n'anya koro evu na oma, "she looks beautiful to the eyes but is rotten inside", or as ochara ocha n'oku atoghi uto n'onu, "a beautiful and attractive dish that tastes badly" (69). ${ }^{4}$ Other themes that surface from Schipper's collection include the physical features of a female body that are considered attractive, the difference between natural and artificial beauty in a woman, and the various consequences of having an attractive physical appearance (87-89). 
In addition to proverbs, many other forms of verbal art may express views on aesthetics, as we shall see below. In the study of aesthetics, the relevant opinions that surface in these various literary forms may be used as a confirmation or supplement to findings yielded by other means, such as the results of examining art criticism. Focusing primarily on the visual arts, the study of artistic or aesthetic criticism has been the main methodological tool in the empirical research into African aesthetics.

The number of art scholars who point to correspondences between the results of empirical studies in visual aesthetics and the views expressed in the verbal arts would still seem to be quite limited. One of these scholars is Loretta Reinhardt (136). In support of her findings that masks among the Mende of Sierra Leone emphasize features of ideal female beauty--like a large forehead, abundant hair, and a ringed neck--she refers to a Mende praise song published by Sjoerd Hofstra in which these same characteristics are stressed (182):

\author{
My child, big forehead, \\ woman with plenty of hair. \\ O big forehead, \\ O my child, fine neck.
}

Such comparisons may be made to the mutual benefit of the two domains involved, for it could be argued that while the lyric underscores Reinhardt's observations on sculptural aesthetics, the latter in turn shed new light on the praise song collected by Hofstra. ${ }^{5}$

Kate Ezra similarly corroborates her findings on the aesthetics of the nyeleni statues 
among the Bamana of Mali with references to a form of verbal art. Nyeleni are female figures which are used by members of the Jo society and can be described as "representations of the physical qualities desired in young, marriageable women" (18). In discussing these qualities, Ezra refers to the lyrics of the bard Seydou Camara from the neigbouring Malinke, another Mande people. ${ }^{6}$ "When Camara's lyrics are examined for the specific traits that are considered beautiful in a young woman, it becomes evident that these same features are emphasized in the nyeleni figures" (18). For example, in one of the songs the ungrateful hunter Famori is transformed into a beautiful woman, whose charms are described as follows (21):

Her breasts completely filled her chest,

Namu...

Her buttocks stood firmly behind her.

When Famori's wife NuntPnPn saves him from his predicament, Camara praises her by describing identical features, adding

Look at her slender, young bamboo-like waist,

NuntPnPn is the favorite forever.

In another song by Camara, an antelope called DagwP is transformed into a woman, whose physical attractiveness is described in similar terms, with the following addition 
Her neck was ridged with fat.

Her buttocks were so nicely shaped.

Eee, this DagwP woman is really pretty.

Ezra concludes that "The projecting breasts, jutting buttocks, and slim waists of the nyeleni figures correspond to the ideal of female beauty and sexual attractiveness set forth in these songs" (21). ${ }^{7}$ Camara's lyrics thus focus our attention on certain visual or morphological characteristics of nyeleni and other female Bamana figures, such as the elongated, pole-like middle part of the torso which students of Bamana statuary art might not have previously considered an accentuated rendition of a slender waist that adds to a figure's beauty.

In his exposition of Yoruba visual art and aesthetics, Adepegba similarly draws on various literary types, such as If $<$ divination verses, proverbs, and even popular song lyrics. For example, in referring to the famous Ife brass and terra cotta heads, he first observes that "Apparently they are all idealized, mostly representing people in their prime with features like the eye and the neck corresponding to the Yoruba's people's standard of human beauty" (17). The eyes, especially in women, should be well-delineated, and the neck is highly esteemed when it overfolds or 'spirals'. Adepegba subsequently points out that these views on female beauty also surface in the lyrics of a song recorded by the contemporary Yoruba musician Ebenezer Obey, which enumerate the attributes a man should look for in a woman $(17):^{8}$

Eleyinyu ege 
She who has seductive well delineated eyes

Awelorun bi okoto

She whose neck is spiralled like a snail shell

Eji жопи еji

She who has gaps in both her upper and lower teeth

One of the first scholars to combine research into visual aesthetics with references to the verbal arts is Robert Thompson. Reporting on his study of artistic criticism among the Yoruba, he observes that one of the major principles used in the evaluation of sculpture is $X w b^{*} n t d n w b * n s X$ or moderation, conceived of as a mean between extremes. Having outlined the importance of this criterion, Thompson (58-59) cites the Yoruba writer Amos Tutuola who observes in his Feather Woman of the Jungle: "She was indeed a beautiful woman. She was not too tall and not too short. She was not too black and not yellow". ${ }^{9}$ The question as to the degree of catholicity of the aesthetic views expressed in literary types evidently becomes more pressing in the case of more individualized products such as contemporary novels. As the above example demonstrates, the opinions communicated herein may well be in keeping with what research suggests to be consensual views, so that these literary products can at times indeed be referred to as confirming results obtained by other means.

In his essay on Yoruba artistic criticism Thompson also provides references to other Yoruba verbal arts, such as a fable and a verse from the If $<$ divination literature $(29,31-32)$. Yoruba scholars have suggested that particularly the If $<$ literature provides an important source of information on Yoruba concepts of beauty. Thus, Wande Abimbo*la has argued that every 
serious student of Yoruba art, aesthetics, and culture must take into consideration the divination verses of the If< oracle, which he considers the most authorative among the many genres of Yoruba oral literature. Examining If $<$ poetry, he argues, "sheds wonderful light on Yoruba life and thought. Through the study of Ifa one discovers the philosophical concepts that are the basis for understanding Yoruba aesthetics" (11). A similar observation has been made by Abio*dun ("Verbal" 252), and particularly native Yoruba scholars are indeed to an increasing degree referring to If< poetry in their analyses of Yoruba art and aesthetics (e.g., Abio*dun "Future", Lawal). The divination verse referred to by Thompson (29), quoting Beier and Gbadamosi (30), is rendered in the following English translation:

Anybody who meets beauty and does not look at it will soon be poor.

The red feathers are the pride of the parrot.

The young leaves are the pride of the palm tree.

The white flowers are the pride of the leaves.

The well-swept verandah is the pride of the landlord.

The straight tree is the pride of the forrest.

The fast deer is the pride of the bush.

The rainbow is the pride of heaven.

The beautiful woman is the pride of her husband.

The children are the pride of the mother.

The moon and the stars are the pride of the sun.

Ifa says: beauty and all sorts of good fortune arrive. 
Thompson also provides an interpretation of this verse, concluding that "the moral is clear: aesthetic sensibility brilliantly embarks a man upon his career" (30). If < divination verses relating to art and beauty are likely to play a prominent role in future discussions of Yoruba aesthetics and philosophy of art, which may lead to an interesting confrontation of the exegesis provided by the babal $<w o$ or If $<$ priests (see, e.g., Adepegba 15) and the interpretations of these verses, including their exegesis, by both native and non-native scholars of Yoruba art and culture.

The well-known Yoruba $\operatorname{orRkX}$ or praise poems or songs, especially those concerning various types of artists, would seem to present another important source for Yoruba aesthetics, in addition to providing valuable information on other aspects of Yoruba art and artistry (see, e.g., Pemberton). For example, the following fragment of the $\operatorname{orRkX}$ of the sculptor Taiwo of IlaO*rangun (ca. 1855-1935) appears to emphasize the importance in male anthropomorphic figures of well-delineated eyes, a clearly rendered mouth, the presence of a broad and powerful chest, and the rendition of a circumcised penis (Pemberton 126): ${ }^{10}$

[40] Baba o*ko* mi

$\left[\mathrm{gbJ}^{*}\right.$ gi $1 \mathrm{jd} \backslash \mathrm{gbJ}{ }^{*} \mathrm{gi}$ lJ*nu

[ gbJ*gi nR gPngP ByB

$[1<\mathrm{ke} * \mathrm{tP} * 1 \mathrm{rR}$ ok $\backslash$

Baba o*ko* mi AjBl< 
[45] [ gbJ*gi olljd o gbJ*gi o lJ*nu

$[\mathrm{gbJ} * \mathrm{gi} \backslash \mathrm{nR} \mathrm{gPngP}$ ByB

Baba o*ko* mi AjBl<

[ gbJ*gi o l<ke*tP* pJnpJ 1|rR ok\

[40] My father in law.

He carved wood so that it had eyes and a mouth.

He carved it so that it had a broad and powerful chest.

He carved the penis with a cap [i.e., circumcised].

Ajala, my father in law.

[45] His carving properly depicts the eyes and the mouth.

His carving has a broad and muscular chest.

Ajala, my father in law.

His carving depicted the penis perfectly with its cap.

It will be clear that one cannot safely draw conclusions concerning Yoruba sculptural aesthetics on the basis of the clues provided in a sculptor's praise poem, but such clues may serve as an incentive to further investigation, or may, once again, be used as a confirmation of research results obtained by other means. More generally, an appropriate interpretation of artists' orRkX not only presupposes an intimate acquaintance with the stylistic devices of the genre, but also assumes an extensive knowledge of the conceptual, sociocultural, and historical background against which the poem is set. As John Pemberton points out (130), 
It is clear that $\operatorname{or} R X X$ for carvers reveal the recognition bestowed upon an artist by his contemporaries and how he is remembered by his descendants. While set phrases, such as, 'One who carves wood as though it were a calabash' and 'He transforms wood into a human being,' are often employed, the $\operatorname{or} R k X$ are highly personal, referring to the carver in the context of his particular lineage and workshop, albeit often in an oblique and highly stylized language dependent upon local knowledge for its understanding.

One may nonetheless be tempted to interpret sculptors' orRkX as providing valuable insights into several dimensions of Yoruba artistry, including those that could be said to go beyond aesthetics, such as artists' self-regard. The latter would seem to be referred to in the following lines from the orRkX of the sculptor Fake*ye* (ca. 1870-1946), who was apprenticed to Taiwo (Pemberton $129):^{11}$

ArP ajJ, bi mo gbJ*nB bR b tB

[25]

BR mo gbJ*nB bR b pJ

Ma roko ma fi mosJ* se

Ma sbwb, ma sX n<jB l'O*jP*

GbigbJ* ni wl*n 'ngbJ*, BRru a*jP*-Ile

Os*J agbJ mirj

[30]

$\mathrm{O} * \mathrm{~b} *$ ni agbJ* rekete $\mathrm{f} * \mathrm{ba}$ 
If Are $\mathrm{O} * \mathrm{je} *$ does not prosper from his creations,

[25] If carving is not profitable,

Then I [Are O*je] shall add farming to my work.

I shall trade and go to the market at $\mathrm{O} * \mathrm{je}$.

But we are carvers, not carriers of ordinary loads

in $\mathrm{O}^{*} \mathrm{je}$.

Carvers who do not carry loads

Are the powerful persons who create beautifully

carved figures for kings.

Although there is no doubt, as Babatunde Lawal reminds us, that "oral tradition" is one "valuable research source not yet fully explored by students of Yoruba art" (xxii), Yoruba scholarship has at least already demonstrated the considerable potentialities of studying the verbal arts in order to understand Yoruba visual art and aesthetics. Indeed, the examples provided in this paper only hint at the richness of Yoruba oral tradition in this regard. The views expressed in the various literary types among the Yoruba may very well be instrumental also in addressing more philosophical questions regarding the arts and their qualities in the Yoruba universe. Abio*dun would seem to be justified in casting an optimistic eye on the future when he argues that "familiarity with Yoruba oral traditions will enhance our present understanding of Yoruba art immensely, as well as the visual arts informing our perceptions of oral traditions. With the progress made so far in Yoruba studies, and the thought-provoking research going on today, the time has come to start asking questions about the nature and concept of art in Yoruba culture" ("Introduction" 46). ${ }^{12}$ 
Intimately related to these art philosophical questions are those that concern the nature of the fundamental quality of $e^{*} w B$ or 'beauty', and its relationship with other central concepts in Yoruba thought. Lawal has recently summarized and discussed diverse views concerning the relationship between $e^{*} w B$ and the complex and crucial notion of $X w B$, variously interpreted as 'existence', 'essential nature', and especially 'character'. Indeed, both the concept of $X w B$ and its relationship to $e^{*} w B$, particularly with respect to human beings, are the subject of debate among scholars of Yoruba culture (26-29). Suffice it here to observe, finally, that in this context Lawal cites the following--anonymous--poem, of which he says that it is "often recited by parents to educate their children" (28):

O*mo* $t^{\prime} \backslash d<$ ra tRkb n'RwB

$\mathrm{O} *$ mo*-langidi ni i

QwB rere $1 \mathrm{P}^{*} \mathrm{~s} \mid * \operatorname{PnXB}$

$\mathrm{B}^{\prime} \mathrm{b} \mathrm{XrRn} \mathrm{d}<\mathrm{ra}$ bR E*gbara

[5] BR kb n'RwB

$\mathrm{O} *$ mo*-langidi ni i

$\mathrm{B}^{\prime}{ }^{*}$ kjnin suwb*n, suwb*n

$\mathrm{BR} \mathrm{e}^{* \mathrm{ja}}$ ind omi

$\mathrm{BR} \mathrm{kb}$ n'RwB rere

[10] O*mo*-langidi ni

If a child is beautiful but has no character 
He is no more than a wooden doll.

Good character is the beauty of a person.

A woman can be as beautiful as the $E^{*}$ gbara $^{13}$

[5] If she has no character

She is no more than a wooden doll.

A man may be very handsome

Like a fish in the water

If he has no character

[10] He is no more than a wooden doll.

The main purpose of this exploratory paper has been to suggest that research into African verbal arts may significantly contribute to the study of African aesthetics as well as philosophies of art. Several problems involved in considering literary types from this perspective have been briefly identified. Among others, these concern the extent to which the opinions expressed in oral or written literature reflect collective views, the proper interpretation of key concepts within the 'textual' and contextual settings in which they occur, and the need for a thorough general background knowledge in order to appropriately interpret the information provided in relevant verbal art forms. However, rather than stressing epistemological and methodological issues, the elaboration of which would require the assistance of literary scholars, emphasis has been placed on the prospects that the study of the verbal arts offers for understanding the views which inform the creation and evaluation of aesthetic and artistic activities in African cultures. The examples provided in this paper, and the brief consideration of Yoruba verbal arts in particular, suggest that 
the potentialities of this type of study are indeed considerable. Together with the intensive study of the aesthetic and artistic vocabulary, a more thorough consideration of relevant forms of literature will therefore have to occupy a more prominent place in our attempts to comprehend African aesthetic views and philosophies of art. As Abio*dun has argued, "The recognition of how important African languages and literatures are to the understanding of African art will lead to a reconsideration of many 'closed' issues, theoretical frameworks, and artistic concepts" ("Future" 64).

\section{NOTES}

${ }^{1}$ See, for example, Anderson; Higgins; Benitez; and Van Damme "World".

${ }^{2}$ This MA thesis, submitted at Alexandria University in 1982, is entitled "Al-Tafseer Al-Jamali li Adawat Al-Zeena ind Majmooat Al-Shaigiya wa Usooluha Al-Tareekhiya", which is translated as "The Aesthetic Interpretation of Shaigiya Ornaments and their Historical Sources" (Abusabib 30, n.31).

${ }^{3}$ A good example of this type of study is Jean Derive's semantical and contextual examination of the various terms for 'beauty' as employed by the Dyula of $\mathrm{C}^{\wedge}$ te $\mathrm{d}^{\prime}$ 'Ivoire in their daily speech and various literary types. Derive presented his paper during a Seminar on 'The Concept of Beauty in Oral Traditions', organized at the University of Leiden by Mineke Schipper and marking an increased interest in examining aesthetics through the study of verbal art forms (for a brief report 
on this seminar, see Jansen).

${ }^{4}$ The physical attractiveness of a girl or woman is circumscribed by the Igbo in a variety of ways, which often draw on referents from the natural environment. "She is referred to as eagle's kola because of her rare beauty and light skin; apunanwu -- 'she does not go out in the sun' because of her delicate form; Mili mma -- 'water of beauty', the result of her sparkling beauty; eje mmili -'she does not go to the stream', a delicate beauty; Mmili uти mma -- 'water of the children of beauty', or 'Asa nwanyi' -- female fish, glossy skin and smooth body. She is finally described as 'enenebe ejeghi olu' -- 'you admire her and forgo the day's work'" (Aniakor 67). Also, "When a girl is well built and has all the physical attributes of manifest beauty, the Igbo refer to her as 'Nwataa dika agbogho mmoo' - 'this girl is like the maiden spirit' or 'eagle in search of beauty' 'Ugonachomma"' (67).

${ }^{5}$ In a special issue of the journal Word \& Image, devoted to the relationship between the verbal and the visual arts in Africa, Abio*dun similarly observes with respect to the Yoruba that "it would be difficult to understand Yoruba art without familiarity with Yoruba literature, particularly the If $<$ literary corpus. In the same way, the study of Yoruba oral tradition is greatly enhanced by the study of the visual art in which the literary concepts are concretized" ("Verbal" 252). Elsewhere, Abio*dun refers in more general terms to "the grossly understudied aspects of African arts, primarily the unity of verbal, visual, and philosophical elements" ("Future" 85). Compare also Lawal who writes that "Among the Yoruba, art and oral tradition are so interrelated that the one 
is like a pictorial abstraction of the other" (xxiii).

${ }^{6}$ Ezra bases herself on Gerald Anthony Cashion's study, Hunters of the Mande: A Behavorial Code and Worldview Derived from a Study of their Folklore. Ph.D dissertation, Indiana University, 1984.

${ }^{7}$ The same visual characteristics are found in Yayoroba, 'the Beautiful Woman', a character appearing in the puppet masquerades of youth associations among the Bamana. The puppet representing Yayoroba, says Mary Jo Arnoldi, "has firm jutting breasts, rounded buttocks, and a slender waist" (174). In this case, too, a song lyric is called upon to confirm that these visual characteristics are considered to lend beauty to a woman. Arnoldi points to what she calls the "signature song" of the Yayoroba character, which is sung during her performance, and includes verses that "celebrate her soft skin, her ample size, and her pleasing pear-shaped proportions" (174).

${ }^{8}$ Ebenezer Obey and His International Brothers, Vol. 4, Decca, WAPS 48, 1972, side 2, track 3.

${ }^{9}$ A passage from The Arrow of God, a work by another Nigerian author, the Igbo Chinua Achebe, has also attracted the interest of scholars dealing with African art and aesthetics. The passage in question reads: "When [the sculptor Edogo] had finished carving the face and head [of the mask] he had been a little disapointed... But the owners of the work had not complained; in fact they had praised it highly. Edogo knew, however, that he must see the Mask in action to know whether it 
was good or bad" (250-51). Several visual art scholars have referred to this passage in underscoring the importance of the dynamic context in which African masks should be seen (for references, see Van Damme Beauty 339, n. 35).

${ }^{10}$ This theme returns in lines $61,64-65,67,71-76$, and $78-85$ of the $\operatorname{or} R k X$ in question; see Pemberton 126-27. Pemberton recorded this $\operatorname{orRkX}$ in Ila-O*rangun in 1992, and acknowledges the assistance of Funs*o S. Afo*layan in translating the transcribed text (136, n.6).

${ }^{11}$ As Pemberton relates, "Recited by Lamidi O. Fake*ye* at Inurin's compound on 25 March 1992 in Ila-O*rangun. I am grateful to Funs*o S. Afo*layan for transcribing the tape recording and assistance in translating the text" (136, n.13).

${ }^{12}$ The oral tradition of less well-studied African cultures may be similarly revealing in terms of local philosophical views on the idea of 'art', as is demonstrated by Zadi GrJkou and SJri DJdy's analysis of the Bete myth of Sr,1,.

${ }^{13}$ Lawal explains that this is a "beautiful rat" (28).

\section{WORKS CITED}

Abimbo*la, Wande. "Preface." Yoruba: Nine Centuries of African Art and Thought. Ed. Henry J. 
Drewal, John Pemberton III, and Rowland Abio*dun. New York: The Center for African Art and Harry N. Abrams, 1989. 11.

Abio*dun, Rowland. "Verbal and Visual Metaphors: Mythical Allusions in Yoruba Ritualistic Art of OrR." Word \& Image 3.3 (1987): 252-70.

-----. "The Future of African Art Studies. An African Perspective." African Art Studies: The State of the Discipline. Rowland Abio*dun et al. Washington, D.C.: The National Museum of African Art, 1990. 63-89.

------. "Introduction: An African (?) Art History: Promising Theoretical Approaches in Yoruba Art Studies." The Yoruba Artist: New Theoretical Perspectives on African Arts. Ed. Rowland Abio*dun, Henry J. Drewal, and John Pemberton III. Washington, D.C., London: Smithsonian Press, 1994. 37-47.

Abusabib, Mohamed A. African Art: An Aesthetic Inquiry. Uppsala: Almqvist \& Wiksell, 1995. (Acta Universitatis Upsaliensis, Aesthetica Upsaliensia 6).

Achebe, Chinua. The Arrow of God. London: African Writers Series, 1965.

Adepegba, C. O. "The Essence of the Image in Religious Sculptures of the Yoruba of Nigeria." Nigeria Magazine 144 (1983): 13-21.

Anderson, Richard L. Calliope's Sisters: A Comparative Study of Philosophies of Art. 
Englewood Cliffs, NJ: Prentice-Hall, 1990.

Aniakor, Chike. "Female Imagery and Presence in Igbo Arts: The Example of Igbo Maiden Spirit Masking." Baessler-Archiv, Neue Folge, 43.1 (1995): 67-88.

Arnoldi, Mary Jo. Playing with Time: Art and Performance in Central Mali. Bloomington, Indianapolis: Indiana UP, 1995.

Beier, Ulli, and Bakare Gbadamosi. Yoruba Poetry. Lagos: Black Orpheus, 1959.

Benitez, Eugenio (ed.). Proceedings of the Pacific Rim Conference in Transcultural Aesthetics. Sydney: U of Sydney, 1997.

Derive, Jean. Beauty: Its Objects and Its Criteria in Dyula Literature. Paper presented at the Seminar 'The Concept of Beauty in Oral Traditions', University of Leiden, March 5-6, 1998.

Ezra, Kate. A Human Ideal in African Art: Bamana Figurative Sculpture. Washington, D.C.: Smithsonian Institution Press, 1986.

GrJkou, Zadi, and SJri DJdy. "Vers une dJfinition de l'art bJtJ: le mythe de Sr,1,." Annales de l'UniversitJ d'Abidjan, sJrie F (Ethno-sociologie) 7 (1978): 49-76. 
Higgins, Kathleen M. (ed.). Aesthetics in Perspective. Fort Worth: Harcourt Brace College Publishers, 1996.

Hofstra, Sjoerd. "Ancestral Spirits of the Mendi." Internationales Archiv fhr Ethnographie 49.1/4 (1940): 177-96.

Jansen, Jan. "Seminar: The Concept of Beauty in Oral Traditions, Leiden, March 5-6, 1998." Newsletter Research School CNWS 16 (1998): 77-79.

Lawal, Babatunde. The $G P^{*} l P^{*} d J^{*}$ Spectacle: Art, Gender, and Social Harmony in an African Culture. Seattle, London: U of Washington P, 1996.

Mate, Bwenge Kule. "Le beau dans la culture nande: essai d'une esthJtique." ZaVre Afrique 214 (1987): 239-50.

Memel-FotL, Harris. "La vision du beau dans la culture nJgro-africaine." Colloque sur la fonction et la signification de l'art nPgre dans la vie du people et pour le peuple, Tome I. Paris: PrJsence Africaine, 1967. 47-68.

Pemberton, John. "Introduction: In Praise of Artistry." The Yoruba Artist: New Theoretical Perspectives on African Arts. Ed. Rowland Abio*dun, Henry J. Drewal, and John Permerton III. Washington, London: Smithsonian Institution Press, 1994. 119-36. 
Reinhardt, Loretta R. Mende Carvers. Ann Arbor: University Microfilms International, 1976. (unpublished Ph.D. dissertation).

Schipper, Mineke. Een vrouw is als de aarde: Afrikaanse spreekwoorden en zegswijzen over vrouwen. Baarn: Ambo, 1994.

Thompson, Robert Farris. "Yoruba Artistic Criticism." The Traditional Artist in African Societies. Ed. Warren L. d'Azevedo. Bloomington, London: Indiana UP, 1973. 18-61.

Tutuola, Amos. Feather Woman of the Jungle. London: Faber and Faber, 1962.

Van Damme, Wilfried. Beauty in Context: Towards an Anthropological Approach to Aesthetics. Leiden, New York, K’ln: E.J. Brill, 1996. (Philosophy of History and Culture, 17).

------. "World Philosophy, World Aesthetics, World Art Studies." Literature and Aesthetics 9 (1999) (in press).

Yankah, Kwesi. "Proverbs: The Aesthetics of Traditional Communication." Research in African Literatures 20.3 (1989): 325-46. 